\title{
Analisis Sentimen Masyarakat Terhadap Virus Corona Berdasarkan Opini Masyarakat Menggunakan Metode Naïve Bayes Classifier
}

\author{
Suhardiman \& Fitri Purwaningtias \\ Fakultas Teknik Ilmu Komputer, Universitas Bina Darma \\ Email: Suhardiman@gmail.com
}

\begin{abstract}
The current use of social media is not only to communicate between friends, but is often also used as a means to convey an aspiration to the community, especially the Indonesian people regarding government issues, or problems related to health and other problems. One of the uses of this social media is to use it as a means of conveying digital aspirations, such as some slogans that are used as hashtags, namely \#dirumahaja \#lockdown, \#usemasker, \#protocol, \#imun, \#vaccine. From the slogan used as a hashtag, researchers are interested in conducting research on how much negative sentiment and positive sentiment there are, using the Naïve Bayes Classifier method, which is a machine learning method that uses probability calculations. The basic concept used by Nave Bayes is the Bayes Classifier Theorem, which is a theorem in statistics to calculate probability, the Bayes Optimal Classifier calculates the probability of one class from each existing attribute group, and determines which class is the most optimal, as for the advantages of using Nave Bayes Classifier in document classification can be viewed from the process that takes action based on existing data to provide solutions to these sentiments.
\end{abstract}

Keywords: Social Media, Hastag, Naive Bayes

\section{Pendahuluan}

Media sosial saat ini telah menjadi tren dalam komunikasi pemasaran. Media sosial adalah sebuah media online, dimana para penggunanya bisa dengan mudah berpartisipasi, berbagi, dan menciptakan isi meliputi blog, jejaring sosial, wiki, forum dan dunia virtual. Blog, jejaring sosial, dan wiki merupakan bentuk media sosial yang paling umum digunakan oleh masyarakat di seluruh dunia. Media sosial sebagai sebuah kelompok aplikasi berbasis internet yang membangun di atas dasar ideologi dan teknologi Web, dan yang memungkinkan penciptaan dan pertukaran user- generated content.

Pemanfaatan mediasosial ini tidak hanya untuk berkomunikasi antara teman saja, akan tetapi sering juga dijadikan sebagai sebuah sarana untuk menyampaikan suatu aspirasi bagi masyarakat khususnya masyarakat indonesia mengenai masalah pemerintahan, ataupun masalah yang berhubungan dengan kesehatan dan permasalahan lainnya. Pemanfaatan media sosial ini salah satunya adalah dijadikannya sebagi sarana menyampaikan aspirasi digital seperti beberapa selogan yang dijadikan sebuah hastag yaitu \#dirumahaja \#lockdown, \#pakaimasker, \#protokol, \#imun, \#vaksin. Dari selogan yang dijadikan hastag ini peneliti tertarik untuk melakukan penelitian mengenai seberapa banyak sentiment negative dan sentiment positif.

Slogan \#dirumahaja \#lockdown, \#pakaimasker, \#protokol, \#imun, \#vaksin yang dijadikan hastag ini adalah sebuah hastag yang muncul diakibatkan berkembangnya infeksi virus corona disebut COVID-19 (Corona Virus Disease 2019). Virus ini menular dengan sangat cepat dan telah menyebar ke hampir semua negara, termasuk Indonesia, hanya dalam waktu beberapa bulan.Hal tersebut membuat beberapa negara menerapkan kebijakan untuk memberlakukan dengan sebutan hastag \#dirumahaja \#lockdown, \#pakaimasker, \#protokol, \#imun, \#vaksindalam rangka mencegah penyebaran virus Corona. Hastag tersebut adalah salah satu sebuah tindakan yang dilakukan pemerintah. Data permulaan 
yang telah didapat yaitu sentiment masyarakat mengenai \#dirumahaja \#lockdown, \#pakaimasker, \#protokol, \#imun, \#vaksin baik sentiment positif maupun negatif.

Adapun permasalahan peneliti mengangkat judul mengenai sentimen masyarakat terhadap virus corona terhadap hastag \#dirumahaja \#lockdown, \#pakaimasker, \#protokol, \#imun, \#vaksin adalah untuk mengetahui mengenai keluhan masyarakat mengenai hastag tersebut, pada sentimen negatif misalnya: banyak yang mengeluh mengenai masalah ekonomi yang berdampak pada kebutuhan pangan untuk sehari-hari begitu juga bagi pedagang yang tidak bisa berjualan, bagi mahasiswa mengeluhkan tugas kuliah yang menumpuk dan masih banyak lagi lainnya mengenai sentimen negatif. Pada sentimen positif masyarakat merasa aman dengan kondisi dirumah, dimana masyarakat dapat berkumpul dengan keluarga, dan bagi dosen dapat melakukan aktifitas yang fleksibel yaitu semua aktifitas dapat dilakukan melalui layanan internet dan masih banyak lagi lainnya mengenai sentimen positif.

Dari penjelasan diatas mengenai selogan pemerintah yang dijadikan selogan digital yaitu hastag \#dirumahaja \#lockdown, \#pakaimasker, \#protokol, \#imun, \#vaksinmaka penelitia menginginkan agar mendapatkan informasi mengenai setimen apa yang terjadi pada masyarakat baik sentimen positif maupun sentimen negative dapat berdampak baik bagi masyarakat. (Bustami, 2019). Adapun penelitian ini menggunakan metode Naïve Bayes Classifier yang salah satu metode machine learning yang menggunakan perhitungan probabilitas. Konsep dasar yang digunakan oleh Naïve bayes adalah Teorema Bayes Classifier, yaitu teorema dalam statistika untuk menghitung peluang, Bayes Optimal Classifier menghitung peluang dari satu kelas dari masing-masing kelompok atribut yang ada, dan menentukan kelas mana yang paling optimal, adapun kelebihan dari penggunaan Naïve Bayes Classifier dalam klasifikasi dokumen dapat ditinjau dari prosesnya yang mengambil aksi berdasarkan data-data yang telah ada untuk memberikan solusi dari sentimen tersebut.

Dalam analisis data, media sosial yang digunakan adalah twitter. Twitter ini berisi data yang bisa termasuk kedalam golongan sentimen positif ataupun sentimen negatif, twitter ini merupakan layanan jejaring sosial dan mikro blog daring yang memungkinkan penggunanya untuk mengirim dan membaca pesan berbasis teks hingga 140 karakter akan tetapi pada tanggal 07 November 2017 bertambah hingga 280 karakter yang dikenal dengan sebutan kicauan (tweet) Wiyadi (2017). Adapun alasan mengapa peneliti memanfaatkan twitter yaitu data tweet dari sosial media ini diizinkan oleh pihak twiiter untuk dijadikan bahan penelitian.

Berdasarkan uraian di atas maka yang menjadi permasalahan dalam penelitian ini adalah hastag \#dirumahaja \#lockdown, \#pakaimasker, \#protokol, \#imun, \#vaksin.

\section{Tinjauan Literatur}

\subsection{Analisis Sentimen}

Menurut Liu (2014), Analisis sentimen juga dapat dikatakan sebagai opinion mining. Analisis sentimen dapat digunakan dalam berbagai kemungkian domain, dari produk konsumen, jasa kesehatan, jasa keuangan, peristiwa sosial dan politik pada pemilu. Kecendrungan penelitian tentang analisis sentimen berfokus pada pendapat yang menyatakan atau menyiratkan suatu sentimen positif atau negatif. Pendapat mewakili hampir semua aktivitas manusia, karena pendapat dapat mempengaruhi terhadap perilaku seseorang. Setiap kali kita perlu membuat keputusan, kita ingin tahu pendapat orang lain. 
Dalam dunia nyata, bisnis dan organisasi selalu ingin melihat opini publik tentang suatu produk atau jasa.

\subsection{Media Sosial}

Menurut Evans (2008), media sosial selalu berubah dari waktu ke waktu sehingga memungkinkan seseorang dapat menjadi kedua pihak, yaitu penerima informasi dan juga penyebar informasi. Secara garis besar media sosial bisa dikatakan sebagai sebuah media online, di mana para penggunanya (user) melalui aplikasi berbasis internet dapat berbagi, berpartisipasi, dan menciptakan konten berupa blog, wiki, forum, jejaring sosial, dan ruang dunia virtual yang disokong oleh teknologi multimedia menjadi satu kesatuan yang sulit dipisahkan serta mendorong pada hal-hal baru. Saat ini media sosial yang paling banyak digunakan dan tumbuh pesat berupa jejaring sosial, blog, dan wiki. Merebaknya situs media sosial yang muncul menguntungkan banyak orang dari berbagai belahan dunia untuk berinteraksi dengan mudah dan dengan biaya yang murah ketimbang memakai telepon. Dampak positif yang lain dari adanya situs jejaring sosial adalah percepatan penyebaran informasi. Akan tetapi ada pula dampak negatif dari media sosial, yakni berkurangnya interaksi interpersonal secara langsung atau tatap muka, munculnya kecanduan yang melebihi dosis, serta persoalan etika dan hukum karena kontennya yang melanggar moral, privasi serta aturan.

Sebagaimana yang sudah dijelaskan di atas tentang pengertian media sosial, yakni sebuah media online artinya pengguna media online tersebut dapat berkomunikasi tanpa harus tatap muka. Awal munculnya media sosial pada abad 70-an, tepatnya tahun 1978, saat sistem papan buletin atau bulletin board system (BBS) ditemukan oleh Ward Christensen dan Randy Suess yang merupakan pecinta dunia komputer. Sistem papan ini memungkinkan pengguna (user) untuk bisa berhubungan dengan orang lain memakai surat elektronik atau mengunggah dan mengunduh melalui perangkat lunak yang tersedia saat itu. Ini merupakan awal sebuah komunitas virtual dalam lingkup terbatas. Dengan seiring waktu berjalan munculah berbagai media sosial dengan seabrek keunggulan, keunikan, karakteristik, dan segmentasi yang beragam. Kemunculan sejumlah situs jejaring sosial itu pada intinya bermula dari adanya inisiatif untuk menghubungkan orangorang dari berbagai latar belakang yang ada di seluruh belahan bumi. Dalam perkembangan lebih lanjut, media sosial kini menjadi sarana aktifitas yang masuk kategori digital marketing, karena banyak dijejali kemasan dan muatan pemasaran Salah satu mendasar yang ada pada situs-situs media sosial tersebut adalah fungsi dan layanan jejaring sosial. Layanan jejaring sosial memberikan jasa koneksi aktifitas melalui situs, platform dan dan saran yang berfungsi memfasilitasi pembentukan jaringan atau hubungan sosial di antara beragam orang yang mempunyai ketertarikan, minat (interest), kegiatan, latar belakang, maksud, kepentingan, tujuan, atau korelasi dunia nyata yang sama. Dari uraian sejarah media sosial diatas telah memunculkan berbagai karakteristik jenis media sosial. Maka dari itu pada era ini banyak macam-macam bentuk media sosial yang tercipta dan memiliki perbedaan dan karakteristik sendiri-sendiri. Menurut penelitian Overdrive, suatu lembaga riset pemasaran, jenis aplikasi media sosial saat ini sedikitnya telah mencapai 240 aplikasi yang menawarkan ratusan cara berinteraksi. Dari penelitian tersebut memperlihatkan keunikan interaksi aplikasi media sosial sangat beragam. Dalam bentuk yang simpel, media sosial adalah bentuk lintas komunikasi lewat penyebaran konten. Materi atau konten itu dapat berupa suatu percakapan diskusi, video, opini, foto dan sebagainya. Dalam hal inilah, lembaga pemerintahan harus turut berperan, bergabung dan secara maksimal dapat memanfaatkan fasilitas ini. 


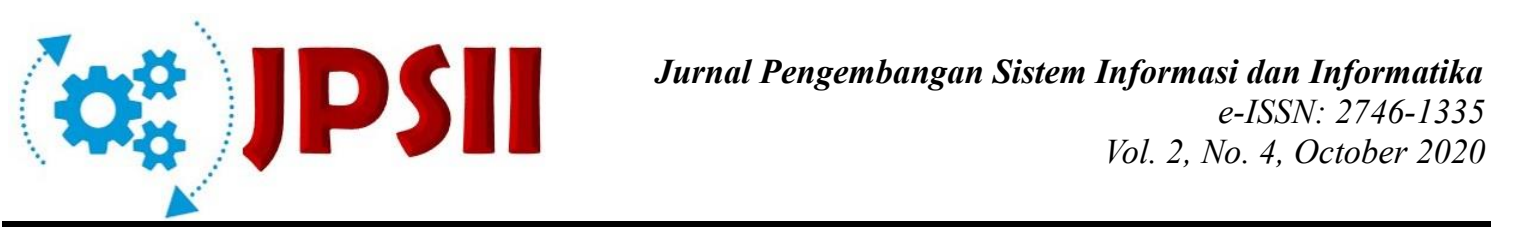

\subsection{Twitter}

Twitter adalah situs microblogging yang dioperasikan olehTwitter, Inc. Disebut micro blogging karena situs ini memungkinkan penggunanya mengirim dan membaca pesan seperti blog pada umumnya. Pesan tersebut dinamakan tweets, yaitu teks tulisan sebanyak 140 karakter yang ditampilkan pada halaman profil pengguna. Perkembangan dunia teknologi semakin memudahkan para pengguna Twitter yang kian hari kian bertambah. Melalui aplikasi eksternal yang kompatibel seperti telepon seluler atau dengan SMS, penggunanya dapat mengirim dan menerima tweets langsung dari situs Twitter. Dengan kemudahan seperti ini, Twitter telah mendapatkantempat di seluruh dunia dengan semakin bertambahnya jumlah users. Twitter dibentuk dan diluncurkan pada 2006 oleh Jack Dorsey. Pendirian Twitter, Inc. dibiayai oleh Obvious LLC. Markasnya terletakdi San Bruno, California. Kemudian, server dan kantor Twitter yang lain tersebar di San Antonio, Texas dan Boston, Massachusetts. Twitter menjadi popular pada tahun 2007 pada festival South by South west. Selama acara tersebut berlangsung, pengguna Twitter meningkat dari 20.000 tweets per hari menjadi 60.000 tweets. Pada September 2010, Twitter mengganti logo dan membuat desain.

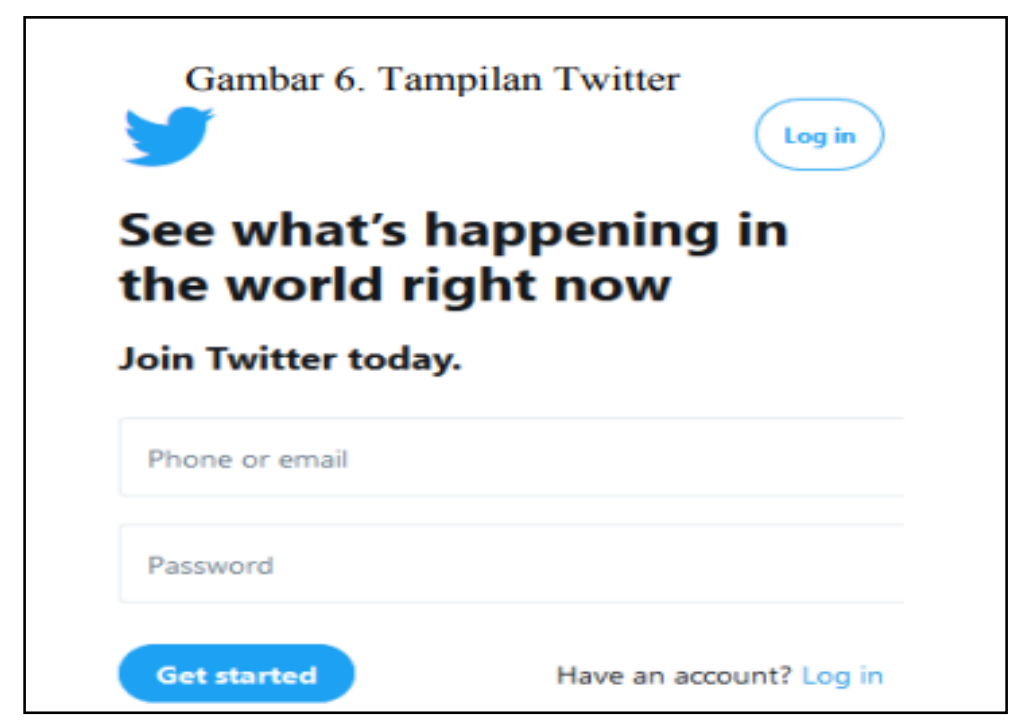

Gambar 3.1 Tampilan Twitter

Dalam menggunakan Twitter, terdapat konten-konten pendukung diantaranya :

a. Home. Home adalah tampilan Twitter setelah melakukan log in. Tampilan ini berisi tweet dari akun-akun yang sudah follow. Home juga biasa disebut dengan timeline. Tweet yang kita tulis juga akan muncul pada timeline orang yang menjadi follower.

b. Profile. Profile adalah tampilan yang terdapat foto, bidata, dan juga aktifitas pengguna akun mulai dari kegiatan tweet, retweet, dsb.

c. Follower. Follower adalah pengguna Twitter lain yang mengikuti kita. Dengan menjadi Follower, pengguna tersebut akan mendapatkan update tweet dari kita.

d. Following. Following adalah pengguna Twitter lain yang kita ikuti. Dengan menjadi following, kita akan menerima update tweet dari akun yang diikuti.

e. Mention. Mention adalah balasan dari percakapan pengguna Twitter dengan menandai akun Twitter yang menjadi lawan bicaranya. Menandai dilakukan dengan 
menulis@dan diikuti nama akun lawan bicara. Mention bersifat publik, sehingga dapat dilihat oleh pengguna lainnya.

f. Favorite. Favorite adalah tweet yang diberi tanda bintang. Dengan demikian, Tweet tersebut tidak akan hilang dari halaman Twitter kita.

g. Replay. Replay adalah konten yang memungkinkan kita untuk membalas pesan/ tweet yang ditujukan kepada kita.

h. Retweet (RT). Retweet atau biasa disingkat RT. Retweet adalah konten yang memungkinkan kita untuk membagikan tweet orang lain dengan maksud sepaham dengan tweet yang ditulis. Retweet tidak menghilangkan akun penulis tweet.

i. $\quad$ Direct Message (DM). Direct Message atau biasa disingkat DM adalah pesan yang dikirim oleh pengguna Twitter secara rahasia. Pesan ini hanya dapat dilihat oleh pengguna Twitter yang dituju.

j. Hashtag (\#). Hashtag atau tanda pagar (\#) adalah simbol yang digunakan untuk memudahkan pencarian/ pengelompokan suatu topik. Semakin banyak pengguna hashtag, maka topik tersebut akan menjadi trending topic.

k. $\quad$ List. List adalah konten yang memungkinkan pengguna Twitter mengelompokkan followingnya sesuai dengan kebutuhan.

1. Trending Topics. Trending topics adalah topik yang sedang menjadi bahan pembicaraan banyak orang. Biasanya diikuti dengan penggunaan hashtag/ tanda pagar.

Dalam pengambilan data twitter yang digunakan teknik crawling yang memanfaatkan Twitter API. Sehingga dengan memanfaatkan Twitter API tersebut, pengguna bisa dengan mudah memperoleh data-data seperti Twitter, data pengguna dan lain-lain. Untuk selanjutnya dikumpulkan dan disimpan dalam sebuah file atau basis data Penelitian yang dilakukan untuk melakukan implementasi teknik.

\subsection{Metode Naive Bayes Classifier}

Menurut Xhemali, Daniela, Chris J. Hinde, and Roger G. Stone. "Naive Bayes vs. decision trees vs. neural networks in the classification of training web pages." (2009), Naive Bayes merupakan sebuah pengklasifikasian probabilistik sederhana yang menghitung sekumpulan probabilitas dengan menjumlahkan frekuensi dan kombinasi nilai dari dataset yang diberikan. Algoritma mengunakan teorema Bayes dan mengasumsikan semua atribut independen atau tidak saling ketergantungan yang diberikan oleh nilai pada variabel kelas. Definisi lain mengatakan Naive Bayes merupakan pengklasifikasian dengan metode probabilitas dan statistik yang dikemukan oleh ilmuan Inggris Thomas Bayes, yaitu memprediksi peluang di masa depan berdasarkan pengalaman di masa sebelumnya.

Menurut Ridwan, Suyono dan Sarosa (2013), Naive Bayes didasarkan pada asumsi penyederhanaan bahwa nilai atribut secara kondisional saling bebas jika diberikan nilai output. Dengan kata lain, diberikan nilai output, probabilitas mengamati secara bersama adalah produk dari probabilitas individu. Keuntungan penggunaan Naive Bayes adalah bahwa metode ini hanya membutuhkan jumlah data pelatihan (Training Data) yang kecil untuk menentukan estimasi paremeter yang diperlukan dalam proses pengklasifikasian. Naive Bayes sering bekerja jauh lebih baik dalam kebanyakan situasi

\section{Metode Penelitian}

\subsection{Pengambilan Data}

Tahap yang digunakan yaitu menyimpan data yang sudah ditemukan kedalam file atau database. 
Berikut ini adalah penjelasannya :

1. Memperoleh kunci Twitter API Hal pertama yang harus dilakukan oleh pengguna adalah membuat akun Twitter. Tujuannya untuk memperoleh API Key, API Secret, Access Token dan Access Token Secret. Langkah- langkah memperoleh key tersebut adalah sebagai berikut:

a. Membuat akun Twitter, apabila pengguna belum memilikinya.

b. Mengakses https://apps.Twitter.com/ kemudian log in menggunakan akun yang telah dibuat sebelumnya.

c. Membuat aplikasi baru, dengan menekan "Create New App"

d. Mengisi form, menyetujui term-term yang ada, dan klik "Create Your Twitter Application".

e. Pada halaman berikutnya, klik tab "Keys and Access Tokens", pengguna dapat melihat API Key, API Secret, Access Token dan Access Token Secret, dan dapat memanfaatkannya pada aplikasinya.

2. Menggunakan library Twitter Pada aplikasi yang dikembangkan, dilakukan import library Twitter. Pada pengembangan menggunakan Java, maka digunakan Twitter.

3. Menghubungkan dengan Twitter Searching API Setelah dilakukan import, selanjutnya adalah menghubungkan apkikasi yang sedang dikembangkan dengan Twitter, caranya adalah memasukkan API Key, API Secret Access Token dan Access Token Secret pada bagian program, dari aplikasi yang sedang dikembangkan.

4. Menyimpan data kedalam file atau database Setelah aplikasi dijalankan, maka hasil dari crawling disimpan dalam file, berupa JSON, XML, CSV, XLS atau ke dalam database.

\subsection{Pengolahan Data}

Sutabri [1] mengemukakan pengolahan data merupakan manifulasi data kedalam bentuk yang lebih berguna dan berarti dimana data tersebut nantinya dapat digunakan untuk kepentingan orang- orang yang membutuhkan.

Setelah melalui tahap pengambilan data pada sentimen masyarakat terhadap Hastag Ganti Presiden 2019 dilakukan perhitungan dengan menghitung nilai probabilitas teks berdasarkan basis pengetahuan yang dimiliki. Terdapat contoh teks yang akan diklasifik.

Tabel 1. Contoh Tweet

\begin{tabular}{lll}
\hline No. & \multicolumn{1}{c}{ Data Tweet } & Sentimen \\
\hline 1. & @ riyan: jaga imun tetap semangat kuat \#imun & Positif \\
2 & @amri: dirumah saja bahaya \#dirumahaja & Negatif \\
3 & $\begin{array}{l}\text { @ sartini: tetap bekerjadan jaga kesehatan } \\
\text { \#protokol }\end{array}$ & Positif \\
\hline
\end{tabular}

\subsection{Proses Preprocessing}


Data latih yang digunakan akan dilakukan tahap preprocessing seperti case pada sentimen masyarakat terhadap Hastag Ganti Presiden 2019 dengan hasil sebagai berikut ini

Tabel 2. Hasil Preprocessing

\begin{tabular}{lllll}
\hline Jaga & Imun & tetap & Semangat & Kuat \\
\hline Dirumah & Saja & bahaya & \\
\hline
\end{tabular}

\subsection{Proses Klasifikasi}

Menurut Hamakonda \& Tarias Klasifikasi merupakan pengelompokan yang sistematis dari pada gagasan, obyek, benda-benda atau buku lain kedalam kelas atau golongan tertentu berdasarkan ciri-ciri yang sama.

Dari hasil Klasifikasi, dilakukan pembentukan fitur sentimen masyarakat terhadap Hastag Ganti Presiden 2019,yaitu menentukan kata yang memiliki nilai sentimen, seperti berikut

Tabel 3. Pembentukan Fitur
Data
Fitur (Kemunculan)
Kelas Sentimen 


Jurnal Pengembangan Sistem Informasi dan Informatika
e-ISSN: 2746-1335
Vol. 2, No. 4, October 2020


Kemudian menghasilkan nilai perhitungan probabilitas Sentimen Masyarakat Terhadap Hastag Ganti Presiden 2019.

Tabel 4. Perhitungan Nilai Probabilitas Setiap Kelas

\begin{tabular}{ccccc}
\hline Kelas Sentimen & & Data(j) & Fd(Cj) & P(Cj) \\
\hline Positif & 1 & 1 & & \\
Negatif & 0 & 1 & 1 & $2 / 2$ \\
Netral & 1 & 1 & 2 & $2 / 2$ \\
\hline
\end{tabular}

\subsection{Proses Hitung Manual}

Melakukan proses prediksi menggunakan metode naive bayes berdasarkan kriteria yang ditentukan. Menurut Ridwan, Suyono dan Sarosa [3], Metode Naive Bayes pada dasarnya merupakan sebuah asumsi yang bertujuan untuk menyederhanakan nilai atribut secara kondisional saling bebas jika diberikan nilai output.

Tabel 5. Proses Hitungan Manual

\begin{tabular}{cccl} 
Id_hastag & Data instagaram $(X 1)$ & Tgl $(X 2)$ & Sentimen (X3) \\
\hline 1 & Happy & $01-12-2016$ & Positif \\
2 & Sad & $01-11-2016$ & Negatif \\
3 & Sad & $01-12-2016$ & Negatif \\
4 & Happy & $01-11-2016$ & Positif \\
5 & Sad & $01-10-2016$ & Negatif \\
6 & Sad & $01-11-2016$ & Negatif \\
7 & Happy & $01-10-2016$ & Positif \\
8 & Sad & $01-12-2016$ & Negatif \\
9 & Sad & $01-11-2016$ & Negatif \\
10 & Sad & $01-12-2016$ & Negatif \\
\hline
\end{tabular}


Tabel 6. Rumus Perhitungan Manual

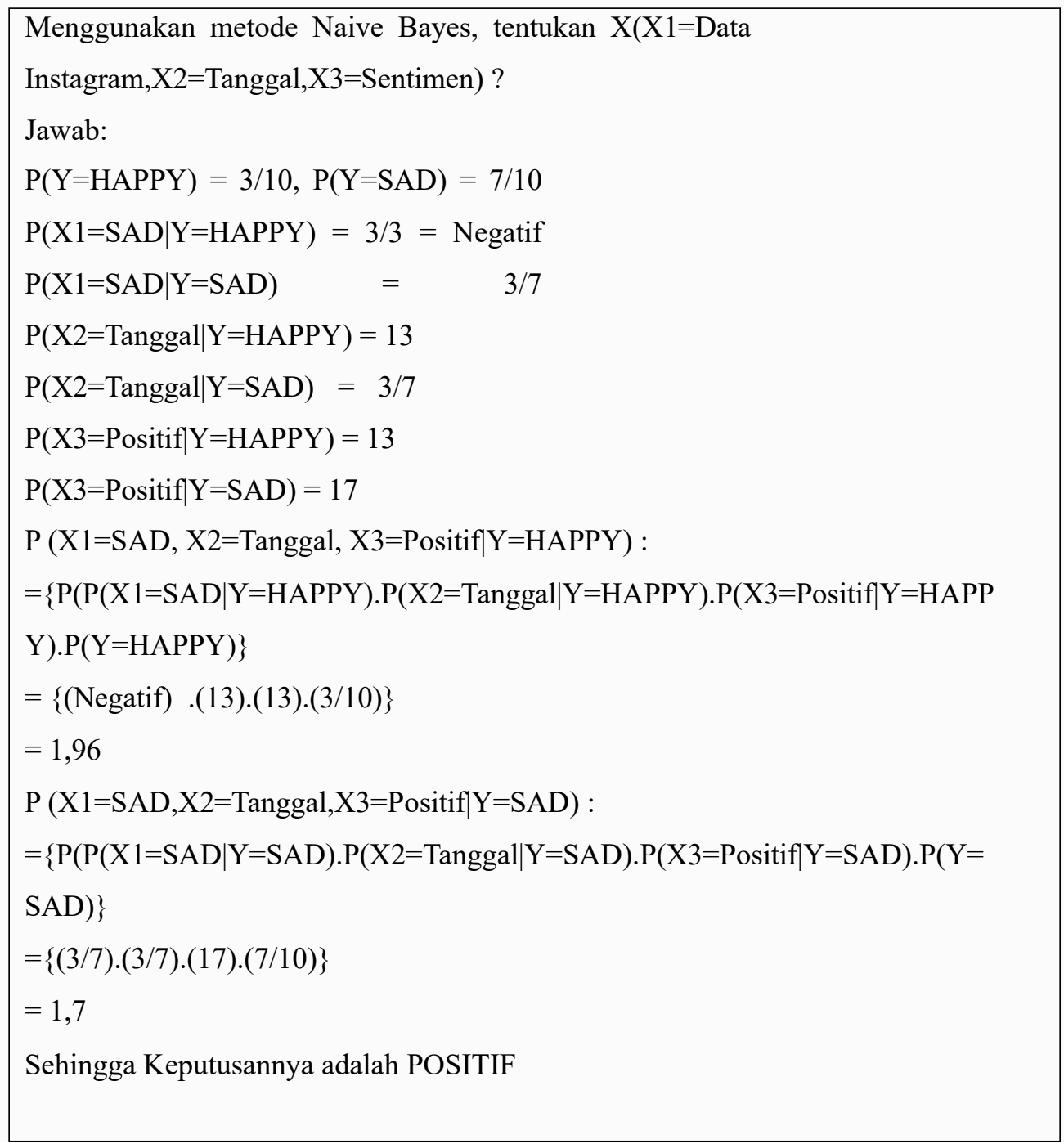

\section{Hasil dan Pembahasan}

Setelah melakukan analisa terhadap perancangan data mining untuk Analisis Sentimen Masyarakat Terhadap Hastag \#dirumahaja \#lockdown, \#pakaimasker, \#protokol, \#imun, \#vaksin Berdasarkan Opini Dari Twitter Menggunakan Metode Naive Bayes Classifier, analisa ini berakhir dengan melakukan proses data mining yang sesungguhnya, maka hasil yang dicapai oleh penulis adalah untuk memprediksi Analisis Sentimen Masyarakat Terhadap Hastag \#dirumahaja \#lockdown, \#pakaimasker, \#protokol, \#imun, \#vaksin Berdasarkan Opini Dari Twitter Menggunakan Metode Naive Bayes Classifier dalam memudahkan proses data mining ini peneliti menggunakan aplikasi weka dari tabel data yang menampung data sentimen \#dirumahaja \#lockdown, \#pakaimasker, \#protokol, \#imun, \#vaksin yang kemudian menghasilkan informasi data sentimen positif, netral dan negatif. Adapun proses pengambilan data sebagai berikut 

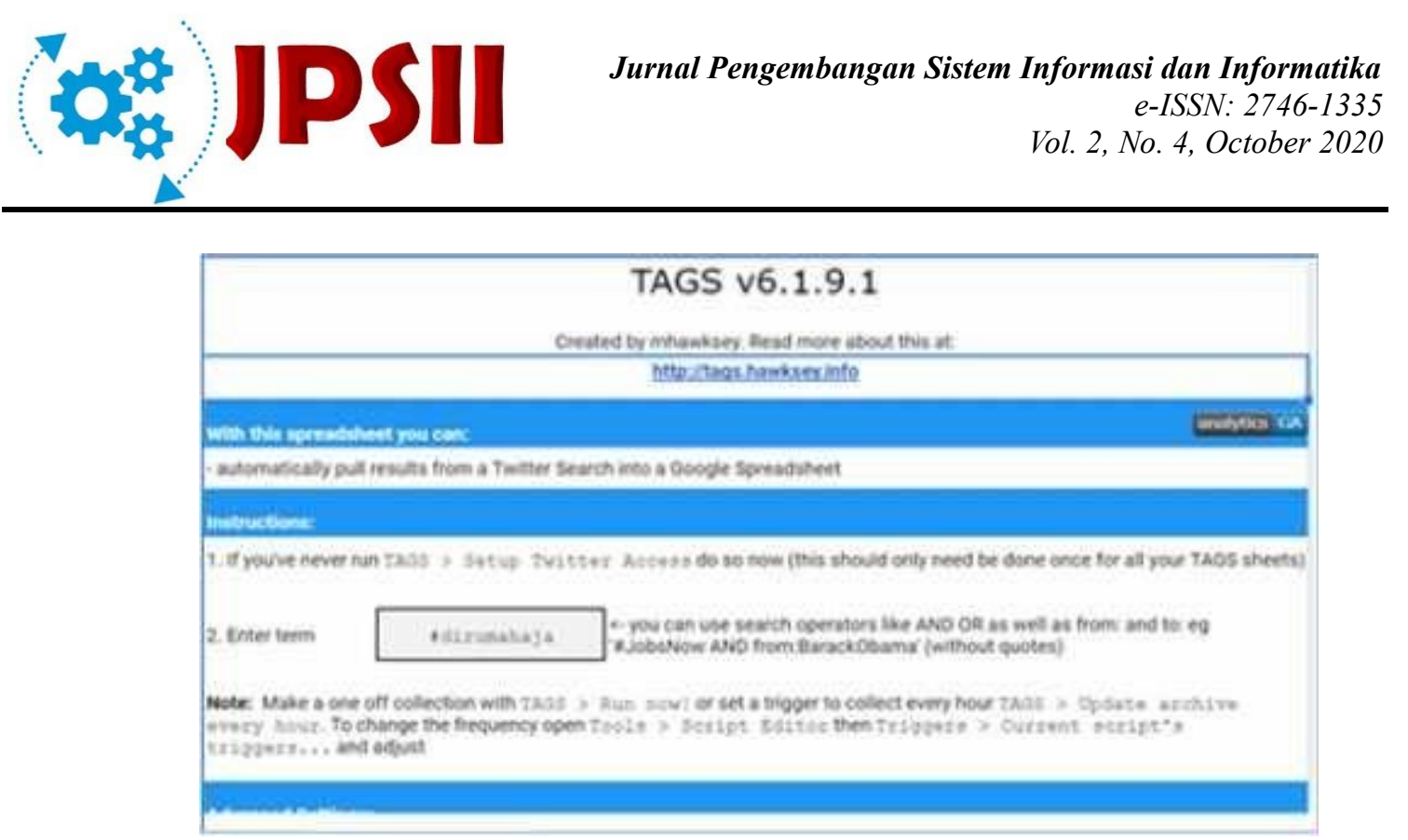

Gambar 4.1 Aplikasi Tags V6.1.9

Gambar 4.1 diatas merupakan tampilan awal pada saat aplikasi dibuka, dimana halaman ini digunakan untuk mendownload data sentiment masyarakat.

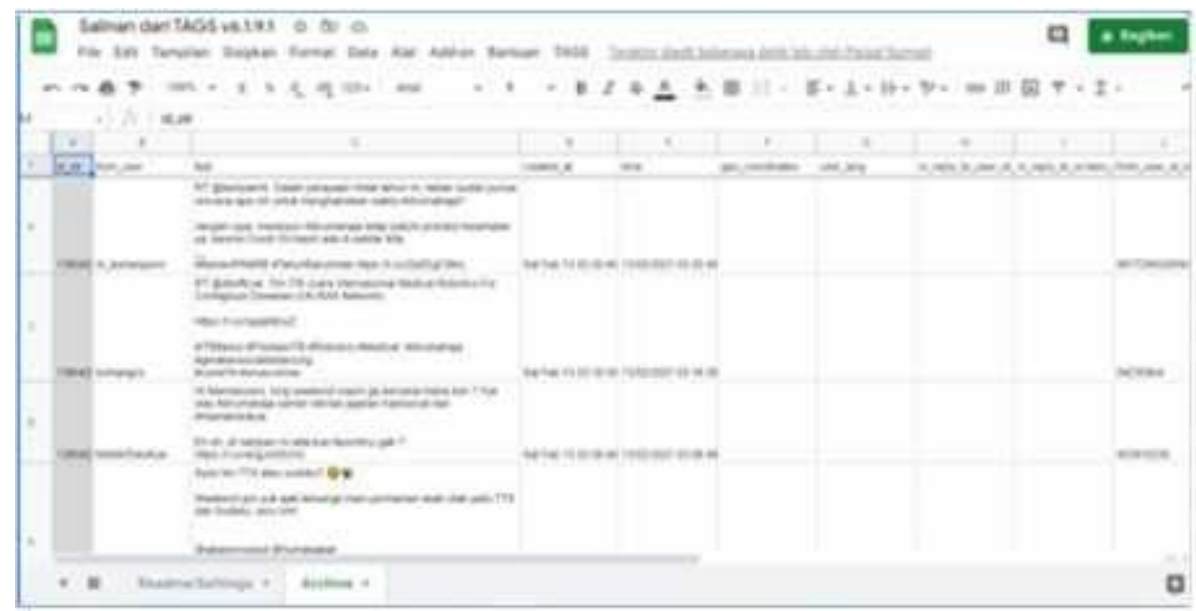

Gambar 4.2 Hasil Pengambilan Data \#dirumahaja \#lockdown, \#pakaimasker, \#protokol, \#imun, \#vaksin

Gambar 4.2 diatas merupakan tampilan setelah proses load dari server twitter, dimana data akan ditampilkan dan biso dilakuka proses download dengan format csv.

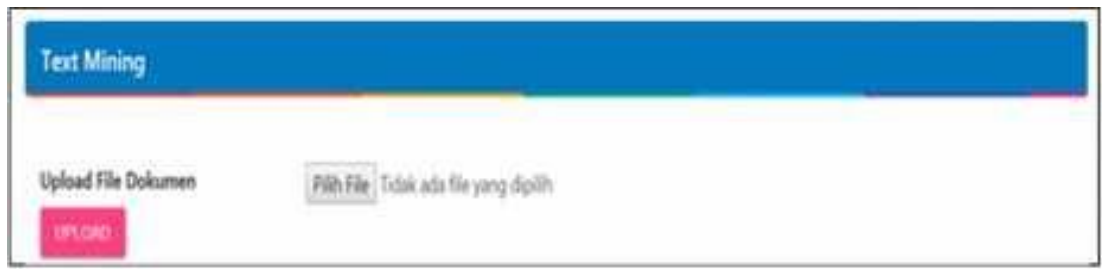

Gambar 4.3 Proses Upload Sentimen Positive dan Negative 
Gambar 3 diatas merupakan tampilan aplikasi text mining pada saat aplikasi dibuka, dimana halaman ini digunakan file csv dilakukan proses konversi untuk mengelompokkan positif dan negative.

\section{Kesimpulan}

Berdasarkan hasil penelitian penulis yang dilakukan serta pembahasan yang dilakukan oleh penulis maka dapat diambil kesimpulan bahwa :

1. Dalam penelitian ini hanya sebatas mengetahui teknik apasaja yang dilakukan dalam proses text mining dengan memanfaatkan data sosial media dari twitter.

2. Sesuai dengan tujuan dari skripsi ini yaitu Analisis Sentimen Masyarakat Terhadap Hastag \#dirumahaja \#lockdown, \#pakaimasker, \#protokol, \#imun, \#vaksin Berdasarkan Opini Dari Twitter Menggunakan Metode Naive Bayes Classifier yang dapat digunakan untuk melakukan evaluasi apakah yang sangat berpengaruh berpengaruh besar terhadapmasyarakat.

3. Proses evaluasi diharapkan dapat memudahkan mendapatkan informasi mengenai data Sentimen Masyarakat Terhadap Hastag \#dirumahaja \#lockdown, \#pakaimasker, \#protokol, \#imun, \#vaksin Berdasarkan Opini dari Twitter yang paling banyak berdasarkan kategori yaitu netral, negatif, positif.

4. Hasil yang didapat dari data Sentimen Masyarakat Terhadap Hastag \#dirumahaja \#lockdown, \#pakaimasker, \#protokol, \#imun, \#vaksin Berdasarkan Opini Dari Twitterberdasarkan kriteria Positif nilai prediksi 93,4\%, netral nilai prediksi 5\% dan negatif nilai prediksi $1,6 \%$

\section{Referensi}

Antoni, D., \& Akbar, M. (2019). E-supply chain management value concept for the palm oil industry. Jurnal Sistem Informasi, 15(2), 15-29.

Antoni, D., Fikari, D., \& Akbar, M. (2018). The readiness of palm oil industry in enterprise resource planning. Telkomnika, 16(6), 2692-2702.

Antoni, D., Herdiansyah, M. I., Akbar, M., \& Sumitro, A. (2021). Pengembangan Infrastruktur Jaringan Untuk Meningkatkan Pelayanan Publik di Kota Palembang. JURNAL MEDIA INFORMATIKA BUDIDARMA, 5(4), 1652-1659.

Antoni, D., Jie, F., \& Abareshi, A. (2020). Critical factors in information technology capability for enhancing firm's environmental performance: case of Indonesian ICT sector. International Journal of Agile Systems and Management, 13(2), 159-181.

B. Liu. 2014. "Sentiment Analysis and Opinion Mining”. Morgan \& Claypool Publisher. Bustami. 2014. "Penerapan Algoritma Naive Bayes Untuk Mengklasifikasi Data Nasabah Asuransi". Vol. 8 Halaman 884-898

Daniela XHEMAL. Christopher J. HINDE2. Roger G. STONE3. 2009. "Naïve Bayes vs. Decision Trees vs. Neural Networks in the Classification of Training Web Pages". IJCSI International Journal of Computer Science Issues. Vol. 4 Halaman 16-23

Eikvil. L. 1999. “Information Extraction from World Wide Web”. 2043.

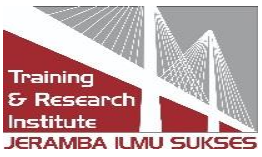


Evans. J.R. and Lindsay W.M. 2008. "The Management and Control of Quality7th Edition”. Ohio: Thomson South-Western.

Fauzi, F., Dencik, A. B., \& Asiati, D. I. (2019). Metodologi Penelitian untuk manajemen dan akuntansi. Jakarta: Salemba Empat.

Kusrini. luthfi taufiq Emha. 2009. Algoritma Data Mining. Penerbit Andi. Yogyakarta

Larose D. T.. 2005. "Discovering knowledge in data : an introduction to data mining". Jhon Wiley \& Sons Inc.

Ridwan. M.. Suyono. H.. \& Sarosa. M. 2013. "Penerapan DataMining Untuk Evaluasi Kinerja Akademik MahasiswaMenggunakan Algoritma Naive Bayes Classifier”. Eeccis. 71.59-64

Santosa. Budi 2007. "Data Mining Teknik Pemanfaatan Data untuk Keperluan Bisnis”. Yogyakarta : Graha Ilmu.

Sitompul. Opim S. 2008. Data Warehouse dan Data Mining untuk Sistem Pendukung Manajemen. Universitas Sumatera Utara. Medan.

Supardi. 2005. "Metodologi Penelitian Ekonomi \& Bisnis”. Yogyakarta : UII Press.

Turban. dkk. 2005. Decision Support Systems and Intelligent Systems. Yogyakarta: ANDI.

Widiarsono. Teguh 2005. “Tutorial Praktis Belajar Matlab”. pdf. Jakarta

Wiyadi. Yudi Permana. 2017. "Pengaruh Tokoh Ahok Pada Media Sosial Menjadi Trending Topic Menggunakan Metode Classification”. Fakultas Teknik Universitas Muhammadiyah Jakarta.

\section{Copyrights}

Copyright for this article is retained by the author(s), with first publication rights granted to the journal.

This is an open-access article distributed under the terms and conditions of the Creative Commons Attribution license (http://creativecommons.org/licenses/by/4.0/) 